\title{
Carcass Yield and Sensory Evaluation of Meat from Rabbits Fed Some Browse Plants Supplemented with a Concentrate Diet
}

\author{
Usman Grace Ojali ${ }^{1, ~ *}$, Netela Jibrin ${ }^{1}$, Omale Yusuf Zainab ${ }^{1}$, Omada Unekwuojo Juliet ${ }^{2}$, \\ Lamido Mohammed ${ }^{3}$, Dauda Adamu Nuhu ${ }^{3}$, Abalaka Ezra Onuh ${ }^{2}$ \\ ${ }^{1}$ Department of Food, Nutrition and Home Science, Kogi State University, Anyigba, Nigeria \\ ${ }^{2}$ Department of Animal Production, Kogi State University, Anyigba, Nigeria \\ ${ }^{3}$ Department of Animal Science, Federal University, Kashere, Nigeria
}

Email address:

ojaligu@yahoo.co.uk (U. G. Ojali)

${ }^{*}$ Corresponding author

\section{To cite this article:}

Usman Grace Ojali, Netela Jibrin, Omale Yusuf Zainab, Omada Unekwuojo Juliet, Lamido Mohammed, Dauda Adamu Nuhu, Abalaka Ezra Onuh. Carcass Yield and Sensory Evaluation of Meat from Rabbits Fed Some Browse Plants Supplemented with a Concentrate Diet. Animal and Veterinary Sciences. Special Issue: Promoting Animal and Veterinary Science Research. Vol. 8, No. 4, 2020, pp. $76-79$.

doi: 10.11648/j.avs.20200804.12

Received: April 29, 2020; Accepted: June 10, 2020; Published: August 5, 2020

\begin{abstract}
Sixteen (16) male Rabbits were allotted into four (4) dietary treatments of four Rabbits each. They were fed concentrate diet and Bamboo, Senna, Gmelina and Teak leaves for 42 days, water was served ad-libitum, at the end of the feeding period 2 rabbits from each treatment were slaughtered and used for the evaluation of carcass yield and sensory properties All the values for carcass yield showed significant $(\mathrm{P}<0.05)$ difference across the treatment means, values for dressing percentage ranged from 51.50- 58\%, while that for meat to bone ratio had a range of 2.80- 3.50. Values for Juiciness, palatability and over all meat quality were significantly $(\mathrm{p}<0.05)$ different across the treatment means. Flavor, tenderness and leanness were however not significant $(\mathrm{p}>0.05) \mathrm{T}_{1}$ (Bamboo) had the best value for overall meat quality with a score of 16.6. It was concluded that the browse species significantly $(\mathrm{p}<0.05)$ influenced, the carcass yield and sensory properties of the rabbit meat. $\mathrm{T}_{1}$ (bamboo) had the best values for carcass yield and sensory properties. Bamboo was therefore recommended for rabbit feeding for improved carcass yield and sensory properties.
\end{abstract}

Keywords: Carcass Yield, Sensory Evaluation, Browse, Concentrate, Rabbits

\section{Introduction}

Meat, plays a major role in human diets as it supplies required nutrients for growth and maintenance of health. [1] According to Oguche et. al., the nutrition of an animal reflects in the meat quality [2] The ideal carcass can be described as one that has a minimum quantity of bone, a maximum quantity of muscle and an optimum quantity of fat. The production of meat from rabbits is suitable because their feeding do not compete for feed ingredients with humans and their meat have some important characteristics which makes it a particularly good meat for human consumption [3], the meat is high in protein and low in fat, the fat in rabbit meat is mainly unsaturated fat, which is believed to be a more healthy type of fat than saturated fat which is common in other meat, the meat has lower cholesterol content than most other meat, this is a health promoting characteristic [4]. The health challenges faced by humans today arising from unhealthy food/ meat consumption calls for the production of meat from animal whose meat is believed to be more healthy, as well as assessing the meat from such animal species, the rabbit is a good example of such animal species

The study was therefore designed to evaluate the effects of some browse species on carcass yield and sensory properties of rabbit meat 


\section{Materials and Methods}

\subsection{Study Area}

The experiment was carried out at the Rabbitary unit of the Teaching and Research Farm of' the Department of Animal production, Kogi State University, Anyigba. Anyigba lies on latitude $7^{\circ} 15^{\prime} \mathrm{N}$ and $7^{0} 29^{\prime} \mathrm{N}$ longitude $7^{\circ} 11^{\circ} \mathrm{E}$ and $7^{0} 32^{\prime} \mathrm{E}$ with average altitude of 420 meters above the sea level. The area lies in derived guinea savannah zone, with average annual rainfall of $1600 \mathrm{~mm}$ the daily temperature ranges from $25^{\circ} \mathrm{C}-35^{\circ} \mathrm{C}[5]$.

\subsection{Experimental Animals, Management, Feed Preparation and Experimental Procedure}

A total of 16 male rabbits were sourced from Anyigba and its environs. They were housed individually in hutches The rabbits were weighed and allotted using Completely Randomized Design CRD) into four (4) dietary treatments, each treatments had four (4) rabbits. the concentrate diet was fed at $50 \mathrm{~g}$ each daily, and the browse (Bamboo, $\mathrm{T}_{1}$ Senna, $\mathrm{T}_{2}$ Gmelina $\mathrm{T}_{3}$ and Teak $\mathrm{T}_{4}$ ) leaves at $100 \mathrm{~g} / \mathrm{rabbit} /$ day Water was given to the rabbits ad libitum. The experiment lasted for 42 days after an adjustment period of seven (7) days.

Table 1. Composition of Concentrate Diet (Dry matter\%).

\begin{tabular}{ll}
\hline Bambara nut offal & 75.60 \\
Rice offal & 24.20 \\
Table salt & 0.20 \\
Total & 100 \\
\hline
\end{tabular}

At the end of the experiment two (2) goats each were sacrificed from each treatment and thereafter used to determine the carcass yield (slaughter weight, dressed weight, dressing percentage and meat to bone ratio) and sensory properties (flavour, tenderness, juiciness, leanness, palatability and overall meat quality). The dressing percentage was calculated from the formula

$$
\text { Dressing percentage }=\frac{\text { Dressed weight }}{\text { live weight }} \times 100
$$

the meat to bone ratio was determined by clearly separating the flesh from the bones, the bones and the flesh were weighed separately and the ratio of the 2 determined Four (4) pieces of meat each weighing $20 \mathrm{~g}$ were cut from the same thigh of two (2) rabbits slaughtered from each treatments (i.e eight (8) pieces of meat for each treatment (eight replicates). The pieces of meat were cut in different shapes to facilitate identification as follows:

$\mathrm{T}_{1}$ - Round

$\mathrm{T}_{2}$ - Triangular

$\mathrm{T}_{3}$ - Square

$\mathrm{T}_{4}$ - Rectangle
Cooking was done at the same time in the same pot. Assessment by a trained taste panel was done at the same time. Each questionnaire was labeled as $\left(\mathrm{T}_{1}, \mathrm{~T}_{2}, \mathrm{~T}_{3}\right.$ and $\left.\mathrm{T}_{4}\right)$, there were eight trained panelists. Each panelist tasted the cooked meat from each of the 4 treatments, four (4) assessments/panelist) and completed the questionnaire provided. There were a total of 32 assessments $(1 \times 4 \times 8)$. The questionnaires were rated on a scale of 1-5 for each parameter as follows according to the method of Ocheja et al., [6]

1. Very good -5

2. Good -4

3. Moderate -3

4. Fair -2

5. Poor - 1

Thereafter the scores for each replicate were added together and divided by 8 to get the mean score for each parameter/treatment. The total score for the five (5) parameters were added together to determine the overall meat quality.

\subsection{Experimental Design and Statistical Analysis}

The experimental design was a Completely Randomized Design (CRD). Data collected were subjected to a one way analysis of variance (ANOVA), means with significant differences were separated using Least Significant Differences (LSD) with the aid of SPSS (2010) version 20.0 [7]

\subsection{Chemical Analysis}

Samples of the concentrate diet and browse species were analyzed for their proximate composition using standard procedure as out lined by AOAC [8].

\section{Results and Discussion}

\subsection{Proximate Composition of Supplement Diet (Dry Matter\%) and Browse Species (Dry Matter \%)}

The proximate composition of supplement diet and the browse plant are presented in Table 2 .

The nutrient in the concentrate and the browse plants are generally adequate for Rabbits in the tropics [4] $\mathrm{T}_{2}$ had the highest protein content of $15.25 \%$ the high ash content of $\mathrm{T}_{1}$ (Bamboo), $10-14 \%$ and $\mathrm{T}_{3}$ (Gmelina), 19.17 suggests high mineral content. [9] The crude protein content of $12.38 \%$ recorded for Gmelina was higher than $10.25 \%$ reported by Abdu et. al [10], the crude fibre content of $18.45 \%$ for Bamboo was lower than $23.3 \%$ reported by Asaolu et al [11], the crude protein and Nitrogen free extracts of the concentrate diet were within the range recommended for growing Rabbits in the tropics [12]

Table 2. Proximate Composition of Supplement Diet (Dry Matter\%) and Browse species.

\begin{tabular}{lllll}
\hline & $\mathbf{T}_{\mathbf{1} \text { (Bambo) }}$ & $\mathbf{T}_{\mathbf{2} \text { (Senna) }}$ & $\mathbf{T}_{\mathbf{3} \text { (Gmelina) }}$ & $\mathbf{T}_{\mathbf{4}}$ (teak) \\
\hline Crude Protein 10.69 & & 15.25 & 12.38 & 10.13 \\
Crude Fibre 18.45 & & 16.67 & 14.02 & 16.30 \\
Nitrogen free extracts & 59.25 & 60.11 & 63.69 & 10.97 \\
\hline
\end{tabular}




\begin{tabular}{|c|c|c|c|c|c|}
\hline & $T_{1 \text { (Bambo) }}$ & $T_{2 \text { (Senna) }}$ & $T_{3 \text { (Gmelina) }}$ & $\mathbf{T}_{4 \text { (teak) }}$ & Concentrate \\
\hline Either extracts 1.45 & & 2.71 & 2.33 & 2.10 & 5.22 \\
\hline Ash 10.14 & & 5.26 & 7.57 & 19.17 & 5.20 \\
\hline
\end{tabular}

\subsection{Carcass Yield of Experimental Rabbits}

The carcass yield of the experimental rabbits is presented in Table 3

Table 3. Carcass yield of Rabbits fed some Browse Species.

\begin{tabular}{llllll}
\hline & $\mathbf{T}_{1}$ & $\mathbf{T}_{2}$ & $\mathbf{T}_{3}$ & $\mathbf{T}_{\mathbf{4}}$ & SEM $^{\mathrm{a}}$ \\
\hline Slaughter weight & $840^{\mathrm{a}}$ & $825^{\mathrm{b}}$ & $785^{\mathrm{c}}$ & $790^{\mathrm{c}}$ & 5.72 \\
Dressed weight & $460^{\mathrm{b}}$ & $465^{\mathrm{a}}$ & $454^{\mathrm{c}}$ & $455^{\mathrm{c}}$ & 2.48 \\
Dressing percentage & $58.70^{\mathrm{a}}$ & $52.00^{\mathrm{b}}$ & $52.75^{\mathrm{b}}$ & $51.50^{\mathrm{b}}$ & 2.34 \\
Meat-Bone ratio & $3.51^{\mathrm{a}}$ & $3.18^{\mathrm{b}}$ & $3.15^{\mathrm{b}}$ & $3.22^{\mathrm{b}}$ & 1.12 \\
\hline
\end{tabular}

$\mathrm{a}, \mathrm{b}, \mathrm{c}=$ Treatment means on the same row with different superscripts differ significant $(\mathrm{p}<0.05)$.

$\mathrm{SEM}=$ Standard Error of Means.

Values for slaughter weight, dressed weight, dressing percentage and meat to bone ratio were all significantly $(p<0.05)$ different across the treatment means values for dressing percentage ranged from $51.50-58 \%$, these values were within the range of 50-56\% reported by fielding [4], a lower range of $43-43.90 \%$ was reported by Musa et, al. [13] all the carcass yield values did not follow an definite trend. the meat to bone ratio ranged from 3.15 to 3.51 , this confirms the report of fielding that rabbits have a relatively high meat to bone ratio [4] the higher carcass yield values for $T_{1}$ (bamboo) could be attributed to better utilization of nutrients, the slaughter weight of 790- $875 \mathrm{~g}$ was higher than $479.70-727 \mathrm{~g}$ reported by Abubakar et. Al [14]. This difference could be due to differences in feeds, breeds and slaughter procedure.

\subsection{Sensory Properties of Experimental Rabbit Meat}

The sensory properties of the experimental rabbits meat is presented in Table 4

Table 4. Sensory properties of Meat of Experimental Rabbits.

\begin{tabular}{|c|c|c|c|c|c|}
\hline & $\mathbf{T}_{1}$ & $\mathbf{T}_{2}$ & $\mathbf{T}_{3}$ & $\mathbf{T}_{4}$ & SEM \\
\hline Juiciness & $3.75^{\mathrm{a}}$ & $3.28^{\mathrm{b}}$ & $3.25^{\mathrm{b}}$ & $3.18^{\mathrm{b}}$ & 0.16 \\
\hline Tenderness & 3.00 & 3.23 & 3.00 & 3.18 & 0.14 \\
\hline Flavour & 3.13 & 3.00 & 3.00 & 2.95 & 0.15 \\
\hline Leanness & 3.30 & 3.20 & 3.30 & 3.25 & 0.85 \\
\hline Palatability & $3.50^{\mathrm{a}}$ & $3.28^{\mathrm{b}}$ & $3.20^{\mathrm{b}}$ & $3.25^{\mathrm{b}}$ & 0.10 \\
\hline Overall meat quality & $16.80^{\mathrm{a}}$ & $15.99^{\mathrm{b}}$ & $15.70^{\mathrm{b}}$ & $15.81^{\mathrm{b}}$ & 0.18 \\
\hline
\end{tabular}

$a, b,-$ Treatment means on the same row with different superscripts different superscripts differ significantly $(p<0.05)$.

$\mathrm{SEM}=$ Standard Error of Means

Values for tenderness, flavor and leanness were not significantly $(p>0.05)$ different, juiciness, palatability and overall meat quality were significantly $(p<0.05)$ different, the values did not follow any definite pattern, the values for palatability ranged from $3.20-3.50$, with $\mathrm{T}_{1}$ having the best, the overall meat quality values ranged from $15.70-16.68$. Ugwuene et al reported non significance $(p>0.05)$ in all the sensory properties evaluated when rabbits were fed forage spice [15].

\section{Conclusion and Recommendations}

\subsection{Conclusion}

Rabbits fed bamboo $\left(\mathrm{T}_{1}\right)$ had the best carcass yield parameters. Rabbits fed bamboo leaves had the best sensory properties

\subsection{Recommendations}

Bamboo leaves is recommended for rabbit feeding for improved carcass yield and sensory properties. The other browse plants can also be used to feed rabbits The experiment can be repeated for a longer duration to further confirm the results obtained in this work.

\section{References}

[1] Anjaneyelu A. S. R, Thomas R and Kondaiah N (2007) Technology for Value added Buffalo meat products: A Review American J. Food Tech 2 (3): 104- 114.

[2] Oguche G. H. E, Ocheja J. O, Omonzokpia O. F, and Jibrin R (2018) Whole Sale cuts amd Organo-Leptic properties of Meat from West African Dwarf Goats fed Diets Containing Graded levels of Cashew Nut Shell Int. J of AGRIC. And Veterinary Science 4 (4); 47-52.

[3] Ocheja J. O, Lalabe B. C, Ebiloma S O, Atabor J. A, Oyibo A and Eniolorunda S. E (2014) Growth and Nutrient Digestibility of Grower Rabbits fed Bambara nut Waste and Rice Offal based Concentrate with Browse Plamts J. Agric. Prod and Tech 3: 30-37.

[4] Fielding D (1991) Rabbits. The Tropical Agricuituralist Series CTA/Macmillan pp. 88-90. 
[5] Ifatimehin O. O., Musa S. D and Adeyemi J. O. (2009). An Analysis of the Changing land use, its impacts on the environment of Anyigba Town, Nigeria. Journal of sustainable Development in Africa 10 (4): 22-29.

[6] Ocheja J. O, Ayoade. J. A, Attah S, Netala J. Ocheni J. and Oyibo A. (2016) Carcass characteristics of growing West African dwarf goats fed diets containing graded level of steam- treated cashew Nut Shell. Animal and Veterinary Science 4 (3-1): 18-22.

[7] SPSS (2010) Statistical package for social science version 20.0. SPSS INC.

[8] AOAC, (1995). Association of Official Analytical Chemist. Official method of analysis. $16^{\text {th }}$ edition, Washington, D. C.

[9] Ambarasu C, Dutta N, Sherma R and Rawat M (2004). Response of Goats to partial replacement of Dietary protein by a Leaf mixture Containing Leuceana leucocephala, Marus alba, and Tectona grandis. Small Ruminat Research 51: 4556.

[10] Abdu S. B, Hassan G. E, Jokthan H. Y, Adamu S. M, Yashim. A and Yusuf K (2012). Effects of Varied Inclusion Levels of Gmelina (Gmelina arborea) Leaf Meal on intake, Digestibility and Nitrogen Balance in Red Sokoto Goats fed Sorghum Grain based Diets. Adv. Agric. Sci Env Res 2: 79-84.

[11] Asaolu v. o, Odeyinka S. M, Akinbamijo O. O, and Shodiende F. G (2010) Effects of Moringa and Bamboo leaves Supplementation on Groundnut Hay Utilization by West African Dwarf Goats. Livestock Research for Rural Development 22 (1): 68-76.
[12] ARC (1980) The Nutrient Requirements of Ruminant of Ruminant Livestock. Agricultural Research Council. Tech Rev. Common Wealth Agricultural Bureau, Slough, U.K P. 352.

[13] Musa M. U and Bello K. M (2011) Effects of Replacing Wheat Offal with Palm kernel Meal on Performanceand Carcass Characteristic of Weaner Rabbits In: Research and Value Addition: Key to Transformation of the Nigerian Livestock Industry A. O Aduku, T. Oluwagbemi, S. O Aribido S. I Daikwo O. J Saliu (Eds) Proceedings of $16^{\text {th }}$ ASAN Conference, Kogi State U niversity, Anyigba, Nigeria pp. 262266.

[14] Abubakar M, Yusuf A. A, Doma D. U, Ibrahim U and Mohammed A, S (2016). Growth, performance, carcass and organ characteristics of growing Rabbits fed graded levels of Moringa oleifera leaf meal In: Reseach and Value Addition: Key to Transformation of the Nigerian Livestock Industry A. O Aduku, T Oluwagbemi, S. O Aribido, S. I Daikwo O. J Saliu (Eds). Proceedingds of $16^{\text {th }}$ ASAN Conference, Kogi State University, Anyigba. Nigeria pp. 365-368.

[15] Ugwuene M. C (2011) Effects of forage spice on Growth, Economics and sensory Performance of weaner Rabbits. In: Research and Value Addition: Key to Transformation of the Nigerian Livestock Industry. O A Aduku, T Oluwagbemi, S. O Aribido, S. I Daikwo, O. J Saliu (Eds) Proceedings of $16^{\text {th }}$ ASAN Conference, Kogi State University, Anyigba, Nigeria pp. 358-361. 